\title{
Publisher Correction: Optomechanical detection of vibration modes of a single bacterium
}

Eduardo Gil-Santos (D), Jose J. Ruz, Oscar Malvar (D), Ivan Favero, Aristide Lemaître (D), Priscila. M. Kosaka, Sergio García-López, Montserrat Calleja and Javier Tamayo

Correction to: Nature Nanotechnology https://doi.org/10.1038/s41565-020-0672-y, published online 13 April 2020.

In the version of this Article originally published online, in Fig. 1a, in the bottom $x$ axis label, the unit for the optomechanical disk radius was incorrectly given as ' $m$ ', and should have been ' $\mu \mathrm{m}$ '. This error has now been corrected in all versions of the Article.

Published online: 29 April 2020

https://doi.org/10.1038/s41565-020-0698-1

( ) The Author(s), under exclusive licence to Springer Nature Limited 2020

\section{Publisher Correction: Programmable multistage drug delivery to lymph nodes}

Alex Schudel, Asheley Poole Chapman, Mei-Kwan Yau (D), Cody James Higginson, David Mark Francis, Margaret Patricia Manspeaker, Alexa Regina Chua Avecilla (D), Nathan Andrew Rohner, M. G. Finn (D) and Susan Napier Thomas (D)

Correction to: Nature Nanotechnology https://doi.org/10.1038/s41565-020-0679-4, published online 10 June 2020.

In the version of this Article originally published, the $y$-axis label in Fig. $3 c$ was incorrect; 'No. of cells positive' should have been 'Percentage of cells positive. This has now been corrected in the online versions of the Article.

Published online: 6 July 2020

https://doi.org/10.1038/s41565-020-0748-8

๑ The Author(s), under exclusive licence to Springer Nature Limited 2020 